\author{
HELENA PIETRZAK \\ Wydział Prawa Kanonicznego \\ Uniwersytetu Kardynała Stefana Wyszyńskiego w Warszawie \\ ORCID: 0000-0003-1260-8139
}

\title{
GODNOŚĆ I RÓWNOŚĆ DZIECKA W RODZINIE
}

Treść: Wstęp. - 1. Godność osoby ludzkiej w ujęciu Kościoła katolickiego. - 2. Zasada poszanowania godności człowieka jako wzorzec kontroli Trybunału Konstytucyjnego. - 3. Konstytucyjna zasada równości w orzecznictwie Trybunału Konstytucyjnego. - 4. Rodzina naturalnym środowiskiem wychowania dziecka. - 4.1. Wpływ religii na sytuację dziecka. 4.2. Dziecko jako członek rodziny. - 4.3. Nakaz poszanowania godności dziecka w procesie wychowania. 4.4. Zakaz stosowania kar cielesnych wobec dziecka. - 5. „Działania pozaprawne” umniejszające godności i równości dziecka. - Podsumowanie.

\section{Wstęp}

Wskazane w tytule artykułu: godność i równość - obejmują szeroki obszar rozważań interdyscyplinarnych (na gruncie prawa międzynarodowego, konstytucyjnego ${ }^{1}$, cywilnego, czy karnego). Pluralizm tych systemów, w tym aksjologia pojęć, powoduje wielorakość ich ujmowania, także w zależności od ogólnego systemu religijnego,

\footnotetext{
${ }^{1}$ Por. A. Mączyński, Konstytucyjne podstawy prawa rodzinnego, w: Państwo prawa i prawo karne. Księga Jubileuszowa Profesora Andrzeja Zolla, red. P. Kardas, T. Sroka, W. Wróbel, T. I, Warszawa 2012; M. GoŁowkin-HudAŁA, Rodzina jako wartość chroniona w Konstytucji na tle europejskich standardów ochrony praw człowieka, w: Polska wobec europejskich standardów praw człowieka, red. T. Jasudowicz, Toruń 2001, s. 89-105.
} 
czy filozoficznego. Stąd też, w zakresie analizy skoncentruję się na ich - podmiocie (dziecku), które podobnie jak dorosły (niezależnie od cech, jego stopnia rozwoju (psychicznego czy fizycznego) - jest właścicielem pewnych praw i wolności (praw człowieka), których źródłem jest właśnie - godność 2 .

Czy jest ona równa „godności osoby dorosłej”? W przepisach - tak, ale już w „niektórych działaniach” - różnych osób dorosłych - nie. Zaprezentuję kilka występujących współcześnie „działań pozaprawnych”, w tym karnych, które umniejszają - godności dziecka, czyniąc go „przedmiotem” czynności rozporządzających osób trzecich (rodziców, opiekunów, pośredników). Skoncentruję się na trzech aspektach: ingerencji bezpośredniej w kształtowanie praw stanu (poprzez komercyjny obrót materiałem genetycznym); następnie - sprzedaż dzieci (z pominięciem adopcji); aż po ocenę uznania godności dziecka - przy realizacji opieki (poprzez wszelkie próby zawłaszczania dziecka, zniewolenia, przemocy czy tresury czyniącej z dzieci narzędzia aspiracji osób dorosłych).

\section{Godność osoby ludzkiej w ujęciu Kościoła katolickiego}

Koncepcja godności osoby ludzkiej i jej szczególna wartość wypływa wprost z Pisma Świętego ${ }^{3}$, została podjęta także w wielu dokumentach Kościoła katolickiego ${ }^{4}$ i nauczaniu papieży. W tym znaczeniu, Kościół odwołuje się do źródeł terminu „godność”,

\footnotetext{
${ }^{2}$ Szerzej por. M. Balcerek, Prawa dziecka, Warszawa 1986; T. Smyczyński, Prawo dziecka do wychowania się w rodzinie, w: Konwencja o prawach dziecka. Analiza i wykładnia, red. T. Smyczyński, Poznań 1999.

${ }^{3}$ Wymiar godności ma swoje urzeczywistnienie w Tajemnicy Wcielenia, bezpośredniej relacji człowieka z Chrystusem „Syn Boży przez wcielenie swoje zjednoczył się jakoś z każdym człowiekiem” por. JAN PAwEŁ II, Encyklika Redemptor hominis, AAS 71 (1979), s. 257-324, tekst polski w: Encykliki Ojca Świętego JaNA PAwŁA II, tom I, Kraków 2005, s. 7-76.

${ }^{4}$ Por. Sobór Watykański II, Konstytucja Gaudium et Spes z 1965 r.; SobóR WATYкAŃski II, Deklaracja Dignitatis humanae z 1965 r.; Jan PAWEŁ II, Encyklika Redemptor Hominis z 1979 r., AAS 71 (1979); JAN PAWEŁ II, Encyklika II Sollicitudo rei socialis $\mathrm{z} 1987 \mathrm{r}$.
} 
potwierdzającego - szczególny status, jaki posiada osoba ludzka wobec innych istnień na ziemi. Stąd też, termin ten w j. łacińskim: dignitas, należy rozumieć jako: zasługę, godność, zacność, wartość osobistą, uczciwość, poważanie, stanowisko ${ }^{5}$.

Kościół katolicki wskazuje na „godność” jako uniwersalną wartość, fundament prawa stanowionego, którą posiada każda osoba ludzka, $\mathrm{z}$ racji bycia - podmiotem i osobą. Z samej nauki Kościoła katolickiego można wskazać kilka typów godności: od naturalnej, nadprzyrodzonej, czy osobowej, poprzez jej wymiary: naturalny i transcendentalny. Ten podział nie jest różnicujący, ale ujmuje wszystko, co dookreśla dignitas. W ramach godności naturalnej, postrzegamy człowieka jako byt samoświadomy i wolny, zdolny do poznania prawdy, górujący nad światem. Wymiar nadprzyrodzony godności, to przejaw bezpośredniej relacji człowieka z Chrystusem, której podstawą jest Tajemnica Wcielenia, potwierdzona definitywnie w Tajemnicy Odkupienia. Ta szczególna relacja oznacza, że człowiek poprzez Chrystusa wchodzi do wspólnoty Osób Boskich. Z niej wywodzi się - godność osobowa, jako najcenniejsze dobro człowieka, ugruntowując go w obiektywnej wartości bytowej względem otoczenia, które przewyższa swoją wartością. Godność ta jest podstawą równości wszystkich ludzi, jest też niezależna od woli i niezniszczalna. Transcendentalny wymiar godności, łączy w sobie aspekty teologiczne, podstawy biblijnej prawdy o podobieństwie człowieka do Boga. Osoba ludzka jest stworzeniem Bożym, żyje życiem podobnym do Boga, posiada te same zdolności poznawcze, rozum, sumienie, samoświadomość, wolność, czy komunijny sposób bycia ${ }^{6}$. Bóg połączył w człowieku dwie materie, które stanowią integralną całość: wymiar cielesny (materię śmiertelną) i wymiar duchowy (nieśmiertelnego ducha). W tym ujęciu człowieczeństwo poprzez swoją naturę, potęguje jego wartość, którego

\footnotetext{
${ }^{5}$ Por. K. Kumaniecki (red.), Słownik łacińsko-polski. Według słownika Hermana Mengego i Henryka Kopii, Warszawa 1999, s. 139 i n.

${ }^{6}$ Por. A. Szostek, Wokół godności, prawdy i miłości, Lublin 1995, s. 325; F.J. MAZUREK, Godność osoby ludzkiej podstawa praw człowieka, Lublin 2001, s. 134.
} 
Stwórca jest źródłem i gwarantem ${ }^{7}$. Zgodnie z nauką Kościoła katolickiego, poszanowanie godności ludzkiej, w tym jej praw, spoczywa na społeczeństwie, które może to osiągnąć poprzez szacunek, uznanie i ochronę transcendentalnej godności człowieka ${ }^{8}$. Wierni, niezależnie od płci, roli, czy funkcji jakie pełnią w Kościele, są równi ${ }^{9}$ w swej nadprzyrodzonej godności.

\section{Zasada poszanowania godności człowieka jako wzorzec kontroli Trybunału Konstytucyjnego}

Także prawodawca konstytucyjny, definiuje i uznaje godność ludzką jako „dobro przyrodzone”. Przy czym termin „przyrodzona” wskazuje na „przynależność gatunkową”, odnosi samą godność człowieka do ludzkiej tożsamości ${ }^{10}$, niezależnie od jego fazy rozwoju (nasciturusa $^{11}$, czy człowieka już urodzonego) ${ }^{12}$. W tym zakresie art. 30 Konstytucji $\mathrm{RP}^{13}$ dookreśla „akceptację jej prawnonaturalnego charakteru i nadrzędności wobec woli ustawodawcy"14. To w prawie naturalnym upatruje źródeł godności, „przynależnej każdej osobie ludzkiej niezależnie od etapu rozwoju jej życia"15. Zasada poszanowania godności człowieka zajmuje centralne miejsce w systemie wartości

\footnotetext{
${ }^{7}$ Por. Rdz 1, 28-31.

${ }^{8}$ Por. Jan PaweŁ II, Orędzie Jego Świętobliwości Papieża Jana Pawła II na XXXII Światowy Dzień Pokoju. 1 stycznia 1999 roku, L’Osservatore Romano 1 (209)1999, s. 4.

${ }^{9}$ Por. kan. 208 Kodeksu Prawa Kanonicznego z 1983 r.

${ }^{10}$ Szerzej zob. H. Pietrzak, Prawo do ustalenia tożsamości w polskim porzadku prawnym, Warszawa 2013.

${ }^{11}$ Por. H. Pietrzak, Curator ventris dla nasciturusa, Studia nad Rodziną 2011 (28-29) nr 1, s. 145-164.

12 Także język polski wobec terminu „przyrodzony” stosuje synonimy: naturalny, dany przez naturę, własny, właściwy sobie, wrodzony, wsobny, immanentny, samorodny, wewnętrzny, inherentny.

${ }^{13}$ Konstytucja Rzeczypospolitej Polskiej z dnia 2 kwietnia 1997 r., Dz. U. 1997 r., $\mathrm{Nr} 78$, poz. 483 ze zm.

${ }^{14}$ Wyrok TK z dnia 15 listopada 2000 r., sygn. akt P 12/99; wyrok TK z dnia 15 października 2002 r., sygn. akt SK 6/02; (dalej jako: TK).

${ }^{15}$ Wyrok TK z 28 maja 1997 r., sygn. akt K 26/96.
} 
konstytucyjnych ${ }^{16}$. Tym samym „orientuje całą Konstytucję na osobę człowieka"17. Wskazując jednocześnie, że godność jest przyznana równo wszystkim, jest też niezbywalna i nienaruszalna ${ }^{18}$. Niedopuszczalne jest jej różnicowanie, czy stopniowanie (niezależnie od rasy, narodowości, obywatelstwa, wieku czy płci). Wymóg poszanowania zasady godności, ma to istotne znaczenie, że to właśnie z niej wywodzą się usytuowane w rozdziale II Konstytucji RP wszelkie prawa i wolności konstytucyjne jednostki ${ }^{19}$. Formuła nienaruszalności godności wiąże się zarówno z zakazem podejmowania działań, które mogą ją ograniczyć lub naruszyć, ale także obliguje władze publiczne do jej ochrony poprzez procedury prawne (system nakazów i zakazów). Działania te powinny uwzględniać „sferę autonomii, w ramach której człowiek może się w pełni realizować społecznie”, nie mogą jednak „prowadzić do tworzenia sytuacji prawnych lub faktycznych odbierających jednostce poczucie godności”20. Warto podkreślić, że Trybunał Konstytucyjny wypowiadając się wielokrotnie w kwestii - zakazu naruszania godności człowieka, podkreślał jego „charakter bezwzględny”, który dotyczy wszystkich (erga omnes). Trybunał w swoim orzecznictwie nie dokonał ostatecznego, jednoznacznego zdefiniowania godności, co więcej przyznał, że „potrzebna

\footnotetext{
${ }^{16}$ Wyrok TK z dnia 23 marca 1999 r., sygn. akt K 2/98.

${ }^{17}$ Tak stwierdził także Trybunał Konstytucyjny w wyroku z dnia 23 lutego 2010 r., sygn. akt P 20/09.

${ }^{18}$ Charakter niezbywalny godności oznacza, że „nie można człowieka jej pozbawić, a on sam nie może się jej zrzec" por. Wyrok TK z dnia 5 marca 2003 r., sygn. akt K 7/01.

${ }^{19}$ Por. B. Banaszak, Konstytucja Rzeczypospolitej Polskiej. Komentarz, Warszawa 2012, s. 214.

${ }^{20}$ „Zakaz naruszania godności człowieka ma charakter bezwzględny i dotyczy wszystkich. Natomiast obowiązek poszanowania i ochrony godności nałożony został na władze publiczne państwa. W konsekwencji wszelkie działania władz publicznych powinny z jednej strony uwzględniać istnienie pewnej sfery autonomii, w ramach której człowiek może się w pełni realizować społecznie, a z drugiej działania te nie mogą prowadzić do tworzenia sytuacji prawnych lub faktycznych odbierających jednostce poczucie godności" (wyrok TK z dnia 4 kwietnia 2001 r., sygn. akt K 11/00).
} 
jest znaczna powściągliwość w treściowym precyzowaniu godności”21. Dał tym samym możliwość dalszej interpretacji ustaw przedmiotowo związanych z prawami i wolnościami człowieka.

\section{Konstytucyjna zasada równości w orzecznictwie Trybunału Konstytucyjnego}

Ustawa Zasadnicza statuuje w art. 32 fundamentalną zasadę równości podmiotów wobec prawa. Zgodnie z jej brzmieniem „wszyscy są wobec prawa równi. Wszyscy mają prawo do równego traktowania przez władze publiczne”. Tak sformułowany nakaz obwarowany został w orzecznictwie TK - koniecznością badania kontekstu zastosowania zasady równości. Trybunał ustala uprzednio, czy adresaci normy charakteryzują się określoną „cechą istotną” w równym stopniu, następnie poddaje ocenie ewentualne naruszenia tej zasady, zarówno dyskryminujące jak i faworyzujące ${ }^{22}$.

Trybunał w swoim orzecznictwie stwierdza, że „postulat równości nie może być utożsamiany z nakazem identyczności praw wszystkich jednostek”, ponieważ każda regulacja prawna wprowadza określone w jej przepisach „zróżnicowanie między podmiotami”23. Taki „nakaz identycznego ukształtowania uprawnień czy obowiązków wszystkich jednostek w warunkach obiektywnie istniejących zróżnicowań" (o charakterze naturalnym, czy faktycznym) prowadzi - w opinii Trybunału - do kolizji z zasadą sprawiedliwości społecznej, a także z zasadą racjonalnego ustawodawcy. Wskazane „zróżnicowanie” ma odpowiadać „istniejącym różnicom między adresatami norm prawnych” o charakterze obiektywnym. Ocena, w tym kluczowa transparentność zróżnicowania podmiotów, ustalenie „cechy istotnej”, uznanie podmiotów za podobne lub odmienne - mieści się w kompetencjach Trybunału. W swojej linii orzeczniczej TK dopuszcza „zróżnicowanie podmiotów prawa charakteryzujących się wspólną cechą istotną”, które nie narusza zasady równości, „pod

\footnotetext{
${ }^{21}$ Wyrok TK z dnia 9 lipca 2009 r., sygn. akt SK 48/05.

${ }^{22}$ Wyrok TK z dnia 6 maja 1998 r., sygn. akt K 37/97.

${ }^{23}$ Szerzej por. Wyrok TK z 23 marca 2010 r., sygn. akt SK 47/08.
} 
warunkiem jasno sformułowanego kryterium (stanowiącego podstawę zróżnicowania)"24. Ten katalog warunków Trybunał stopniowo dookreślał w swoim orzecznictwie, przyjmując charakter i zakres ich dopuszczalności. Po pierwsze, kryterium musi mieć „charakter relewantny, czyli pozostawać w bezpośrednim związku z celem i zasadniczą treścią przepisów”, służyć realizacji tego celu i dookreślonej treści. Czyli musi mieć „charakter racjonalnie uzasadniony, a nie arbitralny”25. Po drugie, kryterium musi mieć także „charakter proporcjonalny”. A więc waga interesu, któremu służy opisywane zróżnicowanie adresatów normy prawnej, musi pozostawać w odpowiedniej proporcji do wagi naruszeń i nierównego potraktowania podmiotów podobnych. Po trzecie, wskazane kryterium, co do zasady, musi „pozostawać w związku z zasadami, wartościami i normami konstytucyjnymi uzasadniającymi odmienne traktowanie podmiotów podobnych”26. Wszelkie odstępstwa, a wręcz „niespełnienie” określonego katalogu warunków, Trybunał traktuje w swoim orzecznictwie jako - „zróżnicowanie niedopuszczalne”, a w konsekwencji naruszające zasadę równości podmiotów wobec prawa ${ }^{27}$.

Wskazany jako wzorzec kontroli art. 32 Konstytucji RP należy rozpatrywać jako całość normatywną. Ust. 2 wymienionej normy precyzuje bliżej znaczenie konstytucyjnej zasady równości, wprowadzając zakaz dyskryminacji we wszystkich sferach życia politycznego, społecznego, czy gospodarczego. W opinii Trybunału, przepis ten „określa granice dopuszczalnych różnicowań podmiotów prawa”. Co oznacza, że „żadne kryterium nie może stanowić podstawy dla różnicowań niesprawiedliwych, dyskryminujących określone podmioty". Konsty tucyjny zakaz dyskryminacji oraz prawo do równego traktowania - stanowią w orzeczeniach TK - zarówno pozytywny, jak i negatywny aspekt konstytucyjnej zasady równości. Każde orzeczenie,

\footnotetext{
${ }^{24}$ Tamże.

${ }^{25}$ Wyrok TK z dnia 12 grudnia 1994 r., sygn. akt K 3/94.

${ }^{26}$ Szerzej por. wyrok TK z 23 października 1995 r., sygn. akt K 4/95.

${ }^{27}$ Tak sprecyzował swoje stanowisko TK w analizowanym wyroku z dnia 23 marca 2010 r., sygn. akt SK 47/08.
} 
które stwierdza „zgodność treści normatywnych z prawem do równego traktowania, oznacza automatycznie zgodność tychże treści z konstytucyjnym zakazem dyskryminacji”28.

\section{Rodzina naturalnym środowiskiem wychowania dziecka}

Mając na względzie aspekt historyczny, w tym historię prawa, należy podkreślić - $\mathrm{z}$ uznaniem i przekonaniem, że rodzina stanowi najstarszą, bo naturalną formę życia społecznego w dziejach ludzkości $^{29}$. Jest podstawowym i naturalnym fundamentem istnienia społeczeństwa, narodu. Posiada hierarchiczną strukturę, wewnątrz której przebiega zorganizowane życie poszczególnych jej członków ${ }^{30}$. Prawidłowe, w tym godne funkcjonowanie rodzin żyjących w określonym społeczeństwie, ma swoje konsekwencje w postrzeganiu narodu i państwa ${ }^{31}$, w tym istotnym założeniu także polskiego prawodawcy wobec najmłodszych członków rodziny - „wychowaniu dla dobra społeczeństwa".

Jednak, należy zaznaczyć, że w minionych wiekach zmianie uległa nie tylko struktura rodziny, ale także jej cele, funkcje i prawa. Rozwój cywilizacji przyczynił się do ewolucji wzajemnych powiązań i postaw $\mathrm{w}$ rodzinie. Zmianie uległy więzi rzeczowe, oparte na pracy i przesłankach materialnych (występujące w samowystarczalnych wielkich rodzinach obejmujących szeroki krąg krewnych), na rzecz więzi emocjonalnych - opartych na szacunku, miłości, przyjaźni i partnerstwie (reprezentatywne dla rodziny małej).

Podobnej zmianie, podlegało samo pojęcie rodziny i zakres jej prawnej ochrony. W powszechnym obiegu, najczęściej stosowane jest pojęcie zawarte w Międzynarodowym Pakcie Praw Gospodarczych, Społecznych i Kulturalnych z 1966 r., („,rodzina jest naturalną i podstawową komórką społeczeństwa i ma prawo do ochrony ze

\footnotetext{
${ }^{28}$ Tamże.

${ }^{29}$ Por. S. Koniński, Socjologia ogólna, Warszawa 1989, s. 161.

${ }^{30}$ Szerzej por. S. Waszczak, Polityka rodzinna, w: Polityka ludnościowa i rodzinna, red. L. Frąckiewicz, s. Waszczak, Katowice 1995, s. 19 i n.

${ }^{31}$ Por. Z. TyszkA, Socjologia rodziny, Warszawa 1976, s. 5.
} 
strony społeczeństwa i Państwa”32). W polskim porządku prawnym nie obowiązuje jednolite, wyrażone expressis verbis pojęcie rodziny, a jedynie norma ustrojowa i liczne definicje legalne (ustawowe). Ustawodawca konstytucyjny preferuje model „rodziny oparty na trwałym związku małżeńskim mężczyzny i kobiety, nakierowany na macierzyństwo i rodzicielstwo"33 , które to znajdują się pod szczególną ochroną i opieką państwa ${ }^{34}$. Z uwagi na występujące w art. 18 Konstytucji RP odrębnie sformułowane dwie instytucje prawne (małżeństwo i rodzina) w doktrynie prawa zwraca się uwagę na ich indywidualne znaczenie, w tym ukonstytuowanie struktury rodziny poprzez narodziny dziecka ${ }^{35}$. Tak przyjęta konstrukcja obejmuje pojęcie rodziny w szerszym zakresie, czyli „rodzinę de iure” (opartą na małżeństwie) oraz „rodzinę de facto” (opartą na związku nieformalnym, w którym wychowuje się przynajmniej jedno dziecko) ${ }^{36}$. W ten sposób specjalną ochroną i pomocą ze strony państwa (w ramach zasady

\footnotetext{
${ }^{32}$ Por. art. 10 i 23 Międzynarodowego Paktu Praw Gospodarczych, Społecznych i Kulturalnych otwartego do podpisu w Nowym Jorku dnia 19 grudnia 1966 r. (ratyfikowanego przez Polskę w 1977 r., Dz. U. z 1977 r., Nr 38, poz. 167).

${ }^{33}$ Por. art. 18, art. 41 ust. 2, art. 233 ust. 1 i Preambułę do Konstytucji Rzeczypospolitej Polskiej z dnia 2 kwietnia 1997 r., Dz.U. 1997 r., Nr 78, poz. 483 ze zm.

${ }^{34}$ Także Trybunał Konstytucyjny w swoich wyrokach podkreślił, że „w świetle konstytucyjnej aksjologii małżeństwo i rodzina stanowią szczególnie ważne wartości konstytucyjne”. Wyrok TK z dnia 18 maja 2005 r., sygn. K 16/04; wyrok TK z dnia 11 maja 2005 r., sygn. K 18/04.

${ }^{35}$ Por. M. JabŁoński, S. Żukowska, Prawo konstytucyjne $w$ formie pytań i odpowiedzi, Wrocław 2003, s. 229; S. L. STADniczeńKo, Rodzina i jej prawa $w$ świetle Karty Praw Rodziny 1983, w: T. Jasudowicz (red.), Prawa rodziny - prawa w rodzinie w świetle standardów międzynarodowych. Materiały Krajowej Konferencji Naukowej Toruń 22-23 X 1998 r., Toruń 1998, s. 22.

${ }^{36}$ Szerzej na ten temat por. A. MĄCzYŃski, Konstytucyjne i międzynarodowe uwarunkowania instytucjonalizacji związków homoseksualnych, w: Związki partnerskie - debata na temat projektowania zmian prawnych, red. M. Andrzejewski, Toruń 2013, s. 86-92; B. Gronowska, T. Jasudowicz, M. Balcerzak, M. Lubiszewski, R. Mizerski, Prawa człowieka i ich ochrona. Podręcznik dla studentów prawa i administracji, Toruń 2005, s. 303.
} 
pomocniczości) prawodawca konstytucyjny obejmuje: małżeństwo i rodzinę ${ }^{37}, \mathrm{w}$ tym równość praw w życiu rodzinnym; ochronę prawną życia prywatnego i rodzinnego; prawo rodziców do wychowywania dzieci zgodnie z własnymi przekonaniami (z uwzględnieniem wychowania i nauczania moralnego i religijnego); prawo matki i prawo rodziny do pomocy ze strony władz publicznych; poszanowanie i ochronę praw dziecka (w tym praw dziecka w rodzinie) ${ }^{38}$.

\subsection{Wpływ religii na sytuację dziecka}

Zasadnicze zmiany, w tym rozwój prawa w ostatnich wiekach, stwarzał większą możliwość ingerencji państwa w sprawy rodzinne, relacje dziecko - rodzic. Ten zakres ingerencji zwiększył - przynajmniej w prawie pisanym, status dziecka ${ }^{39}$. Jednak w dawnym prawie, pozycja dzieci nie była szczególnie korzystna. Dzieci praw w ogóle nie miały, a w konsekwencji nie podlegały prawnej ochronie, traktowane były jak rzeczy (podobnie jak kobiety i dorośli niższego stanu). Jednak uwzględniając realia tamtych czasów, warto podkreślić, że większe upodmiotowienie niższych stanów, przyniosło chrześcijaństwo ${ }^{40}$. Wpłynęło ono również na sytuację prawną dziecka. W szczególności religia wyznawana przez rodziców i aspekt sakramentów, dookreśliły prawne pochodzenie i stan cywilny dziecka ${ }^{41}$. Stało się tak za sprawą powszechnej rejestracji metrykalnej w ustawach trydenckich ${ }^{42}$, która

\footnotetext{
${ }^{37}$ Por. art. 18 , art. 33 ust. 1, art. 47 , art. 48 ust. 1 i 2, art. 53 ust. 3 , art. 71 oraz art. 65 ust. 3, art. 68 ust. 3, art. 72 Konstytucji RP.

${ }^{38}$ Wyrok TK z dnia 4 września 2007 r., P. 19/2007, OTK ZU 2007/207, poz. 94.

${ }^{39}$ Por. H. Pietrzak, Prawo do ustalenia tożsamości..., s. 21-40.

${ }^{40}$ Por. B. Kiereś, Problem dziecka w kulturze przedchrześcijańskiej, w: Dziecko. Studium interdyscyplinarne, red. E. Sowińska, E. Szczurko, T. Guz, P. Marzec, Lublin 2008, s. 13-27.

${ }^{41}$ Por. M. Echavarría, Dziecko i jego wychowanie według św. Tomasza z Akwinu, w: Dziecko. Studium..., s. 74; R. Matysiak, R. RosA, Prawa człowieka - prawa dziecka. Podstawy filozoficzno-aksjologiczne i pedagogiczne, Siedlce 2011, s. 195-197; F. AdAMski, Rodzina. Wymiar społeczno-kulturowy, Kraków 2002.

${ }^{42}$ Sobór Trydencki (1545-1563) do dziś uchodzi za najważniejsze wydarzenie w nowoczesnej historii Kościoła. Trwał ponad 18 lat. Jego kluczowe zapisy wprowadziły nową formę zawierania małżeństwa, eliminując powszechne wówczas
} 
przyniosła wymierne korzyści prawno-duszpasterskie i dała początek rejestracji wiernych w prawie powszechnym. Recepcja uchwał soborowych dała też prawny początek aspektom filiacyjno-spadkowym i administracyjnym dzieci (również osób dorosłych).

Dalszy rozwój prawa prywatnego, szczególne w II poł. XX w. przyniósł ogólne deklaracje dotyczące statusu prawnego rodziny, w tym zapisy dotyczące pozycji prawnej dziecka ${ }^{43}$. Nie znalazły się jednak tam unormowania, które harmonizują wszystkie stosunki między rodzicami i dzieckiem, czy też aspekt jednolitej ingerencji w prawa i obowiązki rodzicielskie ${ }^{44}$. Do dziś istnieją odmienności w obszarze materialnego prawa rodzinnego. Jednak najbardziej niepokojące są - nowe zjawiska w prawie rodzinnym spowodowane odejściem na początku XXI w. od określania pojęciem „rodzina” grupy osób spokrewnionych i postrzeganiem małżeństwa nie jako związku damsko-męskiego. Ten „nowoczesny” kształt stosunków rodzinnoprawnych ma swoje konsekwencje również wobec relacji rodzic - dziecko, w zakresie ingerencji w pochodzenie, tożsamość dziecka i prawa opiekuńczo-wychowawcze.

\subsection{Dziecko jako członek rodziny}

Podstawę funkcjonowania rodziny stanowią - stosunki rodzinno-prawne między jej członkami (rodzicami i dziećmi). Podmiotem centralnym wielu rozwiązań prawnych jest - osoba dziecka jako członek rodziny, w której przychodzi na świat i poprzez urodzenie (lub poczęcie) nabywa w tej rodzinie członkostwo ${ }^{45}$. Jednocześnie

małżeństwa tajne. Reforma objęła szereg zagadnień prawno-administracyjnych, w tym obligatoryjność prowadzenia metryk kościelnych. Dyspozycje soborowe dały początek rejestracji metrykalnej wiernych.

${ }^{43}$ Por. A. Schulz, The state of development of uniform law in the field of European and international family and child law, ELF 2007/6, s. 279.

${ }^{44}$ Por. S. Cretney, Family Law in the Twentieth Century A History, Oxford 2005, s. 773-775.

${ }^{45}$ M. Sopoćko w monografii z 1926 r. podkreśla, że „Rodzina w ściślejszym znaczeniu, jako rodzice z dziećmi, jest pierwszym naturalnym społeczeństwem ludzkim. Już sam wyraz „rodzic” wskazuje, że jej zadaniem jest podtrzymanie rodzaju 
poprzez swoje urodzenie, dziecko aktywizuje katalog praw i obowiązków rodzinno-prawnych.

Dla przejrzystości dalszej analizy, warto w tym miejscu ustalić definicję legalną „dziecka” jako podmiotu, osoby fizycznej, wreszcie członka rodziny. Zgodnie z art. 2 ustawy z dnia 6 stycznia 2000 r. o Rzeczniku Praw Dziecka „dzieckiem jest każda istota ludzka od poczęcia do osiągnięcia pełnoletności”46. Także Konwencja o Prawach Dziecka ${ }^{47}$ w art. 1. definiuje „dziecko” jako „każdą istotę ludzką $\mathrm{w}$ wieku poniżej osiemnastu lat, chyba że zgodnie z prawem odnoszącym się do dziecka uzyska ono wcześniej pełnoletność”. Konwencja w swoim katalogu praw powtarza katalog większości praw człowieka, nie czyniąc różnicowania (człowiek dorosły - dziecko). Nakłada jednak na państwo i dorosłych - obowiązek szczególnej ochrony dziecka. Wskazuje, że dziecko nie jest własnością (a więc przedmiotem). Jako podmiot słabszy od dorosłych, musi posiadać dodatkową ochronę przed siłą i przedmiotowym traktowaniem przez dorosłych. Ratyfikując Konwencję, zarówno samo państwo, jak i osoby dorosłe, zostały zobowiązane do - uznania dziecka, w tym jego „dobra” za „najwyższy cel w traktowaniu człowieka - dziecka”. Zobowiązanie to obejmuje - w sposób szczególny - ochronę dziecka przed wszelkiego rodzaju przemocą (pracą przymusową, niewolnictwem, wykorzystywaniem seksualnym, handlem ludźmi, czy udziałem w działaniach zbrojnych). Państwa, w tym także Polska zobowiązała się do dostosowania działań na rzecz ochrony praw dziecka. Ustanawiając instytucję Rzecznika Praw Dziecka, który stoi na straży praw i wolności dziecka, państwo wspiera dziecko w jego rozwoju.

ludzkiego, wychowanie nowych członków". Por. M. Sopoćko, Rodzina w prawodawstwie na ziemiach polskich (studjum etyczno-prawne), Wilno 1926, s. 6; T. SMYCZYŃski, Uwagi o reformie polskiego prawa rodzinnego, w: Prawa rodziny - prawa w rodzinie w świetle standardów międzynarodowych, red. T. Jasudowicz, Toruń 1999, s. 131-132.

${ }^{46}$ Ustawa z dnia 6 stycznia 2000 r. o Rzeczniku Praw Dziecka, Dz. U. Nr 6, poz. 69.

${ }^{47}$ Konwencja o Prawach Dziecka, uchwalona przez Zgromadzenie Ogólne ONZ 20 listopada 1989 r., Dz. U. Nr 120, poz. 526. 
Dziecko, w ramach relacji rodzinno-prawnej, zazwyczaj korzysta z pomocy opiekuńczo-wychowawczej swoich rodziców, którzy powinni je chronić i reagować na każde naruszenie jego podstawowych praw i wolności. Jednak w nadzwyczajnych okolicznościach, jeśli $\mathrm{z}$ jakiegoś powodu rodzice dziecka nie reagują na łamanie jego praw i wolności, lub sami naruszają jego prawa, to podstawowym obowiązkiem państwa (także nas wszystkich, całego społeczeństwa) - jest jego ochrona, wraz z ingerencją we władzę rodzicielską. Zgodnie z art. 72 Konstytucji „każdy ma prawo żądać od organów władzy publicznej ochrony dziecka przed przemocą, okrucieństwem, wyzyskiem i demoralizacją". W ramach konstytucyjnej ochrony praw dziecka, mieści się także „prawo dziecka do niezakłóconego rozwoju, do ochrony przed wszelkimi formami przemocy, do ochrony zdrowia fizycznego i psychicznego", w tym także zapewnienie dzieciom pozbawionym opieki rodzicielskiej - prawa do opieki i pomocy władz publicznych.

\subsection{Nakaz poszanowania godności dziecka w procesie wychowania}

Wskazane regulacje konstytucyjne i kodeksowe gwarantują rodzicom pierwszeństwo w zakresie realizacji o charakterze bezpośrednim - prawa do wychowania dzieci (zgodnie z własnymi przekonaniami). Zakres ten obejmuje - pierwszeństwo w wykonywaniu funkcji wychowawczej rodziny, w tym kształtowania postaw dziecka, zgodnie z katalogiem własnych przekonań. W wymiarze normatywnym i faktycznym, każde działania wychowawcze podejmowane przez rodziców są ograniczone prawami dziecka, w tym poszanowaniem jego godności ${ }^{48}$. Termin „wychowanie” w literaturze przedmiotu określa się jako „całokształt zjawisk związanych z oddziaływaniem środowiska społecznego i przyrodniczego na człowieka, kształtujących jego tożsamość, osobowość i postawy" ${ }^{49}$. W zakresie materialno-procesowym ukształtował się dwojaki charakter „wychowania" - pośredni i bezpośredni. Wychowanie o charakterze

\footnotetext{
${ }^{48}$ Por. W. SkrzydŁo, Konstytucja Rzeczypospolitej Polskiej z 2 kwietnia 1997 r., komentarz, Kraków 1999, s. 47.

${ }^{49}$ Wielka Encyklopedia PWN, tom 30, Warszawa 2005, s. 77-78.
} 
pośrednim realizowane jest przez szkoły i inne struktury edukacyjne, w tym różne instytucje (np. środki masowego przekazu, Kościoły). Natomiast wychowanie o charakterze bezpośrednim, zgodnie z obowiązującymi przepisami prawa rodzinnego, spoczywa na rodzinie. Niezmiennym pozostaje przepis stanowiący o tym, że dziecko pozostaje pod władzą rodzicielską od urodzenia aż do uzyskania pełnoletniości. Warto w tym miejscu podkreślić, że władza rodzicielska ma źródło w tym, że człowiek na początku życia nie może obejść się bez pomocy i ochrony osób dorosłych (rodziców). Prawo tę potrzebę pieczy, opieki nad dzieckiem, sankcjonuje, dookreślając naturalne stosunki między rodzicami a dzieckiem ${ }^{50}$. Kwestia „wychowania dziecka" obejmuje - sferę fizyczną, a więc dbałość o zdrowie i życie, w tym sprawność fizyczną dziecka, jak i sferę duchową, która mieści w sobie spektrum działań ukierunkowanych na - poczucie godności, poszanowaniu siebie i innych, utrwalaniu reguł etycznych, moralnych zmierzających do rozwoju osobowości dziecka. W aspekcie wychowania dziecka, prawodawca nakłada „obowiązek” po stronie rodziców, bądź opiekunów prawnych odpowiedzialnych za dziecko „wysłuchania i w miarę możliwości uwzględnienia zdania dziecka w toku ustalania jego praw”. Orzecznictwo Trybunału Konstytucyjnego zwraca uwagę na „ochronę praw rodziców przed dowolną, arbitralną ingerencją władzy publicznej" ${ }^{51}$. Co oznacza, że więzi rodzinne nie mogą być podważane w sposób dowolny (np. w oparciu o kryterium - biedy). Ustawodawca przyznając rodzicom, w ramach wychowania, „prawo do zapewnienia dzieciom wychowania moralnego i religijnego zgodnie ze swoimi przekonaniami”, jednocześnie nakazuje odpowiednie zastosowanie art. 48 ust. 1 Konstytucji RP (czyli „stopień dojrzałości dziecka oraz wolność sumienia i wyznania dziecka, a także jego własne przekonania”). Realizacja tego prawa w sposób prawidłowy, eliminuje fakt przymuszania dziecka do określonych przekonań. Każde akty siłowe, przymusu pośredniego, bądź

\footnotetext{
${ }^{50}$ Por. K. JAgIELSKI, Istota i treść władzy rodzicielskiej, SC T. III, Kraków 1996, s. 97.

${ }^{51}$ Wyrok Trybunału Konstytucyjnego z 28 kwietnia 2003 r. K 18/02.
} 
bezpośredniego - naruszają zarówno wolność, jak i godność i równość dziecka w rodzinie i społeczeństwie.

Obowiązujący od 13 czerwca 2009 r. znowelizowany przepis art. 87 k.r.o. ${ }^{52}$ - poszerzyl podstawy osobistych relacji rodziców i dzieci o obowiązek okazywania wzajemnego szacunku przez dzieci i rodziców na zasadzie równowagi „dobra dziecka” i ,interesów rodziców”. Wskazana zmiana merytoryczna wprowadziła - nakaz poszanowania godności dziecka, gdyż w dotychczasowym stanie prawnym miało ono jedynie wymiar wychowawczy, a nie normatywny. Zatem, każdego człowieka, także dziecko - należy traktować - „z poszanowaniem jego godności i praw" (art. $95 \$ 1$ k.r.o.), to znaczy dokładnie tak - jak samego siebie. Najlepiej w tym zestawieniu - „godność" pojmowana jest $\mathrm{w}$ etyce. W klasycznym rozumieniu tego terminu, godność osoby odgrywa rolę istotnego kryterium dla oceny działań etycznie właściwych i niewłaściwych. Jeśli jakaś koncepcja (czy działanie człowieka, rodzica, opiekuna) nie odwołuje się do kryterium godności osoby (ludzkiej), rezygnuje przy tym z fundamentalnej zasady różnicy między dobrem i złem, to po prostu nie jest etyką. Jest wtedy jakimś rzemiosłem, przemysłem, technologią, ale nie etyką.

Określona w tytule artykułu „równość pod względem godności”, wymaga eliminacji działań niebezpiecznych, które prowadzą do uprzedmiotowienia człowieka, umniejszają wartość jego godności, wreszcie łamią zakaz nienaruszalności. Nawet w sytuacjach nadzwyczajnych (zbrodni ustrojów totalitarnych, czy eksperymentów medycznych), jedyną wartość, którą człowiek zdołał ocalić, była właśnie godność. Żadnym zatem działaniem, nie można nikogo jej pozbawić, ograniczyć, czy czasowo zawiesić. Przedmiotowe traktowanie narusza zarówno godność, jak i autonomię drugiej osoby, także dziecka.

\footnotetext{
${ }^{52}$ Art. 87 „rodzice i dzieci są obowiązani do wzajemnego szacunku i wspierania się". Ustawa z dnia 25 lutego 1964 r. Kodeks rodzinny i opiekuńczy, Dz. U. Nr 9, poz. 59, Dz.U. z 2015 r., poz. 2082;
} 


\subsection{Zakaz stosowania kar cielesnych wobec dziecka}

Kwestia wychowania dziecka zgodnie z przekonaniami rodziców (bądź opiekunów prawnych) obejmuje również - zakres stosowania określonych metod i środków wychowawczych, ograniczony normatywnie poprzez art. 40 Konstytucji, zgodnie z którym „Nikt nie może być poddany torturom ani okrutnemu, nieludzkiemu lub poniżającemu traktowaniu i karaniu. Zakazuje się stosowania kar cielesnych". W kontekście interpretacji tej normy, wyrażono w literaturze przedmiotu dwa odrębne stanowiska. Pierwsze, dość sceptyczne, podnosiło, że „samoistne rozumienie zakazu stosowania kar cielesnych rodziłoby podstawy odpowiedzialności rodziców stosujących kary cielesne wobec dzieci”. Wyrażono w związku z tym wątpliwość wobec zamysłu ustrojodawcy, którego wolą nie mogło być „objęcie unormowaniem konstytucyjnym tego typu zachowań” ${ }^{33}$. Drugie stanowisko, bardziej właściwe i przeważające w doktrynie prawa konstytucyjnego i rodzinnego, podnosiło interpretację zakazu stosowania kar cielesnych, odnosząc go (bez ograniczeń podmiotowych) do wszystkich relacji międzyludzkich, w tym także do stosunków rodzinno-prawnych wobec relacji między rodzicami a dziećmi ${ }^{54}$. Słusznie podnoszono, że art. 40 Konstytucji wypełniał lukę w prawie, ponieważ w chwili uchwalania Konstytucji RP, żadna norma prawa polskiego nie przewidywała zakazu stosowania kar cielesnych. Szczególnie, że przepis ten, chociaż sformułowany ogólnie, w praktyce dotyczy jedynej grupy społecznej, wobec której powszechnie stosowano kary cielesne, czyli - dzieci ${ }^{55}$. W tym kontekście, trzy normy konstytucyjne należy analizować łącznie. Zakres art. $40 \mathrm{w}$ związku $\mathrm{z}$ art. 72, który gwarantuje ochronę praw dziecka, należy odczytywać

\footnotetext{
${ }^{53}$ Por. B. Banaszak, M. JabŁoński, Konstytucje Rzeczypospolitej oraz komentarz do Konstytucji RP z 1997 r., Wrocław 1998, s. 80.

${ }^{54}$ Por. W. SkrzydŁo, Konstytucja Rzeczypospolitej Polskiej z 2 kwietnia 1997 r., komentarz, Kraków 1999, s. 40.

${ }^{55}$ Por. J. Mazurkiewicz, J. Zaporowska, Wychowanie bezpasów i kijów, „Rzeczpospolita” z 11 lutego $1998 \mathrm{r}$.
} 
w kontekście - poszanowania przyrodzonej i niezbywalnej godności (art. 30 Konstytucji RP) ${ }^{56}$.

Tak sprecyzowany pogląd doktryny, został w praktyce usankcjonowany przepisami ustawy z dnia 10 czerwca 2010 r. o zmianie ustawy o przeciwdziałaniu przemocy $\mathrm{w}$ rodzinie oraz niektórych innych ustaw $^{57}$. Na podstawie tych przepisów dodany został art. $96^{1}$ Kodeksu rodzinnego i opiekuńczego w następującym brzmieniu: „Osobom wykonującym władzę rodzicielską oraz sprawującym opiekę lub pieczę nad małoletnim zakazuje się stosowania kar cielesnych". Poszanowanie godności dziecka w procesie wychowawczym, opiekuńczym, czy edukacyjnym wymaga od rodzica (opiekuna, nauczyciela), aby w swych działaniach uwzględniali nie tylko ustawową regulację, lecz również konstytucyjne zasady i wartości korelujące przede wszystkim z ochroną dziecka, w tym jego prawami. Każdorazowo, obowiązek poszanowania godności dziecka, wyklucza jakiekolwiek nieludzkie lub poniżające traktowanie. Co więcej, wymaga od rodzica (opiekuna, nauczyciela) - podmiotowego kształtowania relacji z dzieckiem. Możliwość stosowania tzw. odpowiednich środków dyscyplinujących, wyklucza stosowania kary cielesnej.

\section{5. „Działania pozaprawne” umniejszające godności i równości dziecka}

Przechodząc do analizy dwóch pierwszych „działań pozaprawnych”, które umniejszają godność dziecka (czyli: komercyjny obrót materiałem genetycznych oraz sprzedaż dzieci) - należy zaznaczyć, że polski prawodawca - pierwszym zagadnieniem zajął się (jedynie pośrednio) dwa razy. Wprowadzając z dniem 13 czerwca 2009 r. do

\footnotetext{
${ }^{56}$ Por. analizę szczegółową na temat pojęcia godności człowieka w polskim porządku konstytucyjnym: K. Complak, O prawidłowe pojmowanie godności osoby ludzkiej w porzadku RP, w: B. Banaszak, A. Preisner (red.), Prawa i wolności obywatelskie w Konstytucji RP, Warszawa 2002, s. 63 i n.; M. JABŁońsKI, Rozważania na temat znaczenia pojęcia godności człowieka w polskim porządku konstytucyjnym, w: B. Banaszak, A. Preisner (red.), dz. cyt., s. 81-83.

${ }^{57}$ Ustawa z dnia 10 czerwca 2010 r. o zmianie ustawy o przeciwdziałaniu przemocy w rodzinie oraz niektórych innych ustaw, Dz. U. z 2010 r. Nr 125, poz. 842.
} 
k.r.o. pozytywno-prawne pojęcie macierzyństwa (z wyższością matki biologicznej nad genetyczną). Jednak bez jednoznacznej penalizacji działań pozaprawnych pośredników, surogatek, czy klinik współpracujących z pośrednikami w obrocie materiałem genetycznym. Także ustawa z dnia 25 czerwca 2015 r. o leczeniu niepłodności - nie penalizuje wprost handlu komórkami.

Równie mało skutecznie, chronił polski ustawodawca - dzieci poddane (powszechnej dziś) - procedurze sprzedaży (zarówno nasciturusa, jak i niemowlęcia). Nieskuteczność ochrony wynikała z błędnej, nieprecyzyjnej i niejednolitej terminologii (zawartej zarówno w kodeksie karnym, jak i w innych ustawach). Dla porównania - prawodawca międzynarodowy, używa terminu „handel dziećmi”, rozumianego jako „jakiekolwiek działanie lub transakcja, w drodze, której dziecko przekazywane jest przez jakąkolwiek osobę lub grupę osób innej osobie lub grupie osób za wynagrodzeniem lub jakąkolwiek inną rekompensatą" 58 . W ramach takiej transakcji, penalizuje wszelkie działania ukierunkowane na wykorzystanie ofiary (do: żebractwa, prostytucji, pracy przymusowej, przestępstw, handlu organami, czy nielegalnych adopcji).

W polskim porządku prawnym pewna zmiana - na korzyść dzieci, pojawiła się dopiero z dniem 20 listopada 2019 r. ${ }^{59}$ Znowelizowano prawo karne oraz postępowanie cywilne - zaostrzając kary za ciężkie przestępstwa przeciw życiu, zdrowiu i wolności dzieci. Chodzi m.in. o okaleczenie, uprowadzenie, porzucenie czy handel dziećmi. Zgodnie z nowelą „osoba znęcająca się fizycznie i psychicznie nad najbliższym - lub nad inną osobą pozostającą w stosunku zależności od sprawcy - podlega karze więzienia od 3 miesięcy do 5 lat”. Gdy znęcanie dotyczyłoby „osoby nieporadnej ze względu na wiek, stan

\footnotetext{
${ }^{58}$ Por. Protokół fakultatywny do Konwencji o Prawach Dziecka w sprawie Handlu Dziećmi, Dziecięcej Prostytucji i Dziecięcej Pornografii.

${ }^{59}$ Ustawa z dnia 16 października 2019 r. o zmianie ustawy - Kodeks karny oraz ustawy - Kodeks postępowania cywilnego, Dz. U. 2019, poz. 2128. Przed nowelizacją - odpowiedzialność karna groziła jedynie za organizowanie nielegalnych adopcji na szeroką skalę. Nowelizacja powoduje, że bezkarne nie pozostaną również „pojedyncze” nielegalne adopcje.
} 
psychiczny lub stan fizyczny - sprawca podlega karze więzienia od 6 miesięcy do lat 8 ".

Natomiast „znęcanie się ze szczególnym okrucieństwem opatrzono karą od roku do 10 lat”. Jeśli „pokrzywdzony w wyniku tego popełni samobójstwo, sprawcy grozi od 2 do 12 lat więzienia". W nowelizacji podwyższono również kary za bezprawne pozbawienie wolności dziecka lub nastolatka, poniżej 15. roku życia (sprawcy grozi od 3 do 15 lat więzienia). Wymiar kary jest w tym przypadku identyczny jak w przypadku - przestępstwa pozbawienia wolności ze szczególnym udręczeniem. Podniesiono również karę minimalną za handel osobą w wieku poniżej 15. roku życia (z trzech do pięciu lat więzienia). Jeśli chodzi o aspekt podmiotowy odpowiedzialności, warto podkreślić, że prawodawca sankcję karną nałożył zarówno na matkę, jak i osobę przyjmującą dziecko, także osobę, która zatai przed sądem, że oddała dziecko za pieniądze lub inną korzyść.

Weryfikacja wprowadzonej reformy z 2019 r., zostanie dokonana za kilka lat. Do tej pory największy zarzut kierowano wobec - braku kontroli sądowej. Sądy utrudniały weryfikowanie intencji i realnych możliwości osób podejmujących się dalszej opieki nad dzieckiem. Orzecznictwo sądowe nie stawiało znaku równości pomiędzy działaniami osób dopuszczających się pozasądowego obrotu dziećmi, a działalnością handlarzy ludźmi ${ }^{60}$. Nawet, gdy w ramach procederu dochodziło do jednego czy kilku czynów przestępczych (np. poświadczenie nieprawdy, fałszowanie dokumentów), a całość działań była obliczona na komercyjne i pozasądowe przekazanie dziecka. Dodatkowo sądy dokonywały oceny społecznej szkodliwości czynów. Stąd też, w przypadku gdy strony postępowania (biologiczni rodzice, jak

\footnotetext{
${ }^{60}$ Warto dodać, że w 2015 r. polski ustawodawca znowelizował przepisy ograniczające tzw. adopcję ze wskazaniem (aby ukrócić podziemie adopcyjne i handel dziećmi). Po zmianie rodzice mogą wskazać osobę przysposabiającą ich dziecko (jedynie spośród krewnych albo małżonka jednego z nich). Wykluczono - osoby trzecie, umówione przez Internet. Czy po nowelizacji - transakcje handlowe ustały? Niestety - Nie. Strony tego procederu obrały - inną metodę, ukierunkowaną na fałszowanie dokumentów, podszywanie się pod cudzą tożsamość, podawanie nieprawdy do aktu urodzenia.
} 
i osoby chcące przyjąć dziecko) nie podejmowały działań w zamiarze kierunkowym wykorzystania dziecka (np. do prostytucji, pornografii, żebractwa czy w celu pozyskania narządów), a w swym zachowaniu kierowały się chęcią zapewnienia mu lepszych warunków życiowych, szkodliwość ich czynów - sądy oceniały, jako „nieproporcjonalnie mniejsza, aniżeli sprawców dopuszczających się eksploatacji ofiar w ramach przestępstwa handlu ludźmi”.

\section{Podsumowanie}

Problematyka godności i równości, dookreślona w katalogu praw i wolności, występuje w powiązaniu z określonymi obowiązkami. W przypadku dziecka, zakres i charakter prawa, nie powinien różnicować w odniesieniu do - godności i równości osoby dorosłej. Tak jednak nie jest, na co wskazują niektóre przepisy (np. zakaz kar cielesnych). Jako prawa podstawowe, wywodzone są z ogólnego nakazu poszanowania życia rodzinnego i ochrony rodziny. Powszechnie lokuje się je w płaszczyźnie praw i wolności osobistych. Chociaż zarówno rodzice, jak i opiekunowie prawni dziecka korzystają $\mathrm{z}$ autonomii modelu wychowawczego, to jednak nie posiadają uprawnień absolutnych. Każdorazowo wykonywanie tych praw wychowawczych (opiekuńczych), nie może naruszać podstawowych praw dziecka, w szczególności godności i równości. Stąd też, w sytuacji zagrożenia dobra dziecka, zwłaszcza przemocy, okrucieństwa, wyzysku, czy demoralizacji, każdy ma prawo domagać się od władz publicznych podjęcia odpowiednich działań ochronnych (art. 72 ust. 1 Konstytucji). Działania te mogą być podjęte wobec każdej osoby dokonującej określonych negatywnych sytuacji, czy naruszeń wobec godności i równości dziecka, także wobec rodziców, bądź opiekunów dziecka. Godność i równość dziecka w rodzinie, w tym jego dobro jest wartością nadrzędną w stosunku do uprawnień rodziców. 


\section{Children's Dignity and Equality in Family Life}

The dignity and equality mentioned in the title include a wide range of interdisciplinary considerations (based on the international, constitutional, civil or criminal law). This analysis focuses on their subjects (children) who - just like adults, regardless of their features of character or level of mental and physical development - are entitled to certain rights and liberties (human rights) whose source is none other than dignity. Is children's dignity equal to that of adults? Based on the applicable legal regulations, it is; however, in practice, in the context of "certain actions” of various adults, it may not always be so. Several currently occurring „non-legal actions”, including criminal ones - diminishing children's dignity and turning them into „objects” at the disposal of persons in control (parents, guardians, intermediaries) - have been presented. The study concentrates on the following three aspects: (i) direct influence on family legislation (by commercial use of genetic material); (ii) human trafficking (except adoption); and (iii) assessment of the recognition of children's dignity in respect of custody (any attempts at appropriation, enslavement, violence or maltreatment whereby children become instruments of adults' aspirations).

SŁOWA KLUCZOWE: godność; równość; dziecko; rodzina

KEYWORDs: dignity; equality; children; family

\section{Nota o Autorze}

Prof. uczelni dr hab. Helena Pietrzak - kierownik Zakładu Prawa Cywilnego w Katedrze Prawa Polskiego i Międzynarodowego, Wydziału Prawa Kanonicznego Uniwersytetu Kardynała Stefana Wyszyńskiego w Warszawie. 